\title{
A new aestivation strategy for land molluscs: hanging upside down like bats
}

\author{
Zaidett Barrientos ${ }^{1}$ \\ 1. Universidad Estatal a Distancia, Vicerrectoría de Investigación, Laboratorio de Ecología Urbana, 2050 Sabanilla, San \\ José, Costa Rica; zbarrientos@uned.ac.cr
}

\author{
Recibido 13-II-2020 Corregido 21-IV-2020 Aceptado 23-IV-2020 \\ DOI: https://doi.org/10.22458/urj.v12i1.2802
}

\begin{abstract}
Introduction: Many land molluscs survival strategies are still poorly understood or have not been even reported, especially in the Neotropics. Methods: I collected 25 adult Tikoconus (Tikoconus) costarricanus from Reserva Forestal Río Macho, Costa Rica. I kept the specimens for 8 days in terrariums to film their behavior. Objective: To analyse the behavior of $T$. costarricanus, with emphasis on its strategies to survive drought and probably also predation. Results: This snail has at least three unusual behaviors that probably help them reduce dehydration and may be escape from enemies and avoid diseases: hanging upside down like bats, falling and grooming. During aestivation, they compress the body and hang upside down from leaves, like bats hang from perches. They attach to the underside of leaves with mucus from a caudal gland. Disengagement is done with vigorous shell rotations and foot twisting in contorting sequences, and can be done as reaction to direct sunlight, and probably to avoid predators and parasites. They groom their own shell, shell lappets and foot, an unusual behavior among land snails. This species feeds mainly on epiphyllous mosses, algae and lichens, occasionally adding arthropod eggs and carrion. Egg laying is similar to other euconulids and valloniid snails. Conclusions: Aestivating hanging upside down is a drought avoiding trait described here for the first time and is also a new function for the caudal gland mucus. Leaf detaching is done by a contortion sequence of shell rotations and foot twisting; its complexity and duration varies according to the leaf side where the snail is located.
\end{abstract}

Keywords: aestivation, defensive behavior, caudal gland, grooming.
RESUMEN. "Una estrategia nueva de estivación en moluscos terrestres: colgarse como murciélagos". Introducción: Muchas estrategias de sobrevivencia en moluscos terrestres todavía están poco estudiadas o no han sido descubiertas, especialmente en el Neotrópico. Métodos: Recolecté 25 adultos de Tikoconus (Tikoconus) costarricanus de la Reserva Forestal Río Macho, Costa Rica. Mantuve los especímenes 8 días en terrarios para grabar su comportamiento. Objetivo: Analizar el comportamiento de $T$. costarricanus, con énfasis en sus estrategias para sobrevivir a la desecación del ambiente y posiblemente a los depredadores. Resultados: Este caracol tiene al menos tres comportamientos inusuales que le ayudan a reducir la deshidratación y probablemente escapar de enemigos y evitar enfermedades: colgarse como murciélagos, tirarse y acicalarse. Durante la estivación, ellos contraen el cuerpo y se cuelgan cabeza abajo de hojas, como los murciélagos en sus perchas. Ellos se adhieren al envés de las hojas con mucus de su glándula caudal. Para poder tirarse de la vegetación desarrollan una serie de contorsiones compuestas de giros de la concha y torsiones del pie, lo hacen para evitar la incidencia directa de los rayos del sol, y posiblemente, depredadores y parásitos. Ellos acicalan su propia concha, lóbulos de la concha y pie. Esta especie se alimenta principalmente de musgos, algas y líquenes epífilos, ocasionalmente agregan huevos y cadáveres de artrópodos. Depositan sus huevos de manera similar a otros caracoles euconúlidos y vallónidos. Conclusiones: La estivación colgándose como murciélagos es una estrategia para evitar la desecación que se describe aquí por primera vez y representa una función nueva del mucus generado por la glándula caudal. Para separarse del sustrato hacen una secuencia de contorsiones con la concha y con el pie, cuya duración depende del lado de la hoja donde se encuentren.

Palaras clave: caracol terrestre, estivación, comportamiento de defensa, glándula caudal, acicalamiento 
Dehydration is a considerable threat for land molluscs, even in tropical forests. It is also an input for the evolution of different survival strategies (Newell \& Machin, 1976; Asami, 1993; Moreno-Rueda, Ruiz-Ruiz, Collantes-Martín, \& Arrébola, 2009). Internal lamellae, thick and white shells, thick and reflected lips are some of the morphological features that have been mentioned as possible adaptations for water conservation (Giokas, Pafilis, \& Valakos, 2005). Other adaptations include being nocturnal, hiding under logs and rocks, migrating into leaflitter, sticking into crevices in the soil and high aggregations (Hyman 1967; Pomeroy, 1968; Prior, 1985; Withers, Pedler, \& Guppy, 1997; Naranjo, 2003). However, their best known characteristic against drought is the production of an epiphragm, which seals the aperture and is accompanied with interesting physiological changes called aestivation (Hyman, 1967; Cook, 2001). Only aestivation physiology and biochemistry of Mediterranean and some other arid dwelling species have been well studied (Pomeroy, 1968; Arad, Goldenberg, \& Heller, 1989; Withers et al., 1997; Rahman \& Raut, 2010).

Quite different aestivating strategies have been reported for slugs, which dig themselves into the ground and produce a mucus cell that covers their whole body; sometimes they add soil and moss (Hyman, 1967; Cook, 2001; Naranjo, 2003). Although aestivation strategies are of key importance in ecology and distribution of land snails and slugs (Arad, Mizrahi, Goldenberg, \& Heller, 2010), very little research has been done for neotropical terrestrial mollusks.

Another important element in land snail evolution is predation. Most studies have analysed shell variation as antipredatory defence (Vermeij, 2015), but few studies focus on their defensive behaviour, especially in the neotropics. Although snails are considered slow and passive animals, some species have aggressive and active defensive traits (Morii, Prozorova, \& Chiba, 2016). Active defensive traits produce important morphological shell adaptations (Ferrand \& Morii, 2020).

Grooming is a very interesting behavior that has been studied mainly in social vertebrates and invertebrates, where it has important social and antiparasitic functions (Sparks, 1967; Reber, 2011; Wilson et al., 2020). However, allo-grooming and self-grooming have seldom been reported for land snails and no experimental research has been done (Gugler, 1963; Barrientos, 2016; KuźnikKowalska, Proćków, Pląskowska, \& Pokryszko, 2018).

Studied terrestrial gastropods eat mainly plant material, followed by fungi, animals and soil (Speiser, 2001). However, there are also some records of land snails eating algae, mosses, lichens and several parts of higher plants (Speiser, 2001). There is no information about native neotropical euconulids food and feces. Oviposition is another land snail behavior that has been described seldom or poorly.

In Costa Rica, one of the more diverse but little studied land snail's families are the euconulids (Barrientos, 2005). The species Tikoconus (Tikoconus) costarricanus is the most widespread species of the genus and occurs from 760 to 2400 masl throughout the Tilaran, Central and Talamanca mountain ranges (Barrientos, 2019a). This species lives on the leaves of understory shrubs in mature forests; they are very sensitive to modifications that affect moisture in their habitat (Barrientos, 2019b). In previous papers I mentioned briefly its habitat and its aestivation, grooming, egg laying and feeding behaviors and its strategies when disturbed (Barrientos, 2019a, b), but here I analyze them in detail. 


\section{MATERIALS AND METHODS}

In March 2010 I collected 25 individuals of $T$. (T.) costarricanus from La Reserva Forestal Río Macho (Costa Rica) $\left(9^{\circ} 45^{\prime} 56.07^{\prime \prime} \mathrm{N} \& 83^{\circ} 51^{\prime} 47.11^{\prime \prime W}, 1640 \mathrm{masl}\right)$, a tropical lower montane wet forest. All specimens were adults or subadults with a shell diameter over $3,5 \mathrm{~mm}$ and a fully pigmented cephalopodium (Barrientos, 2019a). I brought the specimens to the laboratory, in a lower, dryer and warmer area (1 100masl tropical dry premontane forest), therefore I took special care in keeping the specimens with high humidity and avoiding direct sunlight. Specimens were kept for several weeks in hermetic plastic terraria $(10 \times 10 \times 6 \mathrm{~cm})$ with two to five dicotiledonean leaves brought from the forest where the animals were collected. As this species feeds on epiphylls, I choose medium age leaves $5 \mathrm{~cm}$ long or longer, with more than $25 \%$ of epiphyll cover, from the most common shrubs in the area. Leaves were stored in a refrigerator (around $5^{\circ} \mathrm{C}$ ) to keep the epiphytic algae alive for a longer time. I kept environmental moisture by spraying the leaves before placing them in the terrarium. I put all leaves in the usual position: upper side facing up. Every three days I changed leaves and cleaned terrariums. I kept snails in terraria for three days for acclimatization before starting observations. I observed the specimens during 8 days starting at 12:00 and finished observations at 17:00 in the afternoon. I photographed, filmed and described their behavior. In the results section I also add some field observations about feeding. I did not notice any difference between behaviors done in the field and in the laboratory. I used each specimen several times in each treatment, therefore sample size of treatments may be bigger than the number of snails.

I extracted snails from the terrariums (approximately $21^{\circ} \mathrm{C} / 95 \%$ ) and put them on the upper part of isolated leaves in a shaded area (approximately $21^{\circ} \mathrm{C} / 90 \%$ ) inside the laboratory for description of defensive behaviors, grooming and eating. During these observations I kept moisture as high as possible by periodically spraying the leaves on which I was observing the specimens. I described defecation and oviposition in the terraria. For protective behavior to drought I put the specimens outside the laboratory in a shaded area that was warmer and dryer (approximately $25^{\circ} \mathrm{C}$ / $70 \%$ ) than the laboratory, I did not water the leaves and I always put the specimen on upperleaves. For defence behavior against predators I gently touched the cephalopodium with a pin and separately filmed their reaction while they were on leaves' uppersides and undersides.

Voucher specimens: I deposited voucher specimens in the Zoology Museum of the University of Costa Rica. Catalogue number MZUCR- 242-01 (9 specimens). Costa Rica, Cartago, Orosi, Reserva Forestal Río Macho, at "El llano" water dam. 1 640masl. 945'56.07"N, 8351'47.11"W. Collected on 5 March 2012 by Zaidett Barrientos, Maribel Zúñiga \& A. Induni. (T.: ZB-251).

Ethical, conflict of interest and financial statements: The author declares that she has fully complied with all pertinent ethical and legal requirements, both during the study and in the production of the manuscript; that there are no conflicts of interest of any kind; that all financial sources are fully and clearly stated in the acknowledgements section; and that she fully agrees with the final edited version of the article. A signed document has been filed in the journal archives. 


\section{RESULTS}

Hanging upside down like bats: Whenever I extracted specimens from the terrarium and exposed them to warmer and dryer air, snails hanged themselves from the underside of leaves (sample size=39). It took them one to three minutes to start moving. First they moved from the upperside to the underside, this took approximately 30 seconds. After that, they started the aestivation preparation process which took two to three minutes. Then they raised the head and withdrew tentacles and head in the shell. This was accompanied with soft shell movements. A series of slow and little shell and head movements allowed them to detach the foot's anterior part from the substrate. Mantle extensions (right and left shell lappets and right and left mantle lobes) were kept out of the shell. Mantle extensions partially covered the shell and the anterior part of the foot's sole. Meanwhile, the foot was compressed and a larger part of it was released from the leaf. Finally, the snails hung under the leaf, attached by mucus segregated by the caudal gland. At the end, only the foot posterior section, the caudal pore, the caudal horn -and, less often, a small part of the shell - had contact with the leaf (Video 1). Once they reached the final aestivation posture, they stood still, hanging like bats, except for the occasional brief opening of the pneumostome. They could aestivate in this position for several hours, but I never saw an individual aestivating more than $21 \mathrm{hr}$ in a row (Barrientos, in preparation).

I could interrupt the hanging behavior by watering the surrounding leaf area in order to increase environmental humidity; or by touching them. The first thing they do for reassuming activity was moving the mantle extensions to their normal position, uncovering the sole of the foot anterior section. Then they stretched the head and tentacles. Next, they stretched the foot and the head took contact with the leaf surface forming an arch: only the caudal pore area including the caudal horn and the head were touching the surface, and sometimes a small part of the shell. If the shell was partially attached to the leaf, they moved the shell until it was released. Then they started sliding the head forwards, this cause that the rest of the stretched foot got in contact with the surface. The caudal horn was the last part of the body to be released (Fig. 1, Video 2). The caudal gland mucus formed a thread while the animal was sliding away; sometimes the thread was pretty short, though. Depending on how hardy the thread was, there were three detaching options: 1) the snail continued its displacement until the thread broke (sample size= 20); 2) the snail helped break the thread by lifting the tail (sample size=12) or 3 ), or the snail turned around and cut the thread with the radula (sample size $=5$ ); sometimes it continued grooming and cleaning the caudal pore and horn (sample size $=2$ ).

Defensive behaviors: When I touched or stung the specimens, they reacted by: a) moving the shell as a shield, b) excreting mucus, c) hiding the head, d) moving the tail softly, e) advancing in a different direction, f) making shell-rotation and foot twisting or g) making two or more of these activities. I did not measure the frequency of the reactions. Here I describe the more vigorous movements they make when disturbed.

When the specimens were underleaves with the food extended or contracted while aestivating and were disturbed (sample size=4) or when the sunlight hit them directly (sample size $=2$ ), they performed the shell rotation behavior and the foot twisting behavior.

For the shell rotation, the snails partially or totally withdrew the head and tentacles and detached the foot anterior half from the leaf (Video 3). Then they rotate the shell and twist the foot anterior half from one side to the other, releasing a longer part from substrate each time. The last movements were so vigorous that the shell rotated almost $365^{\circ}$. At the same time, they twisted the foot in a single direction, detaching the foot from substrate and falling to the ground or leaflitter. In one case after 14 seconds of shell rotation the foot posterior half fail to break free from the leaf, so the snail stopped contorting, moved a little forward and tried again. Shell rotation and foot twisting 
took $6.5 \mathrm{~s}$ in average (sample size $=6, \min =1.2, \max =14, \mathrm{sd}=5.3$ ). When the snail finished the contortion sequence, the head and tentacles were completely withdrawn in the shell but the shell lappets and mantle lobes were left outside the shell, the caudal horn was very short and flat (it almost disappeared) and no mucus thread was produced.

When the specimens were on upperleaf the contortion sequence took twice the time, $12 \mathrm{~s}$ in average (sample size $=6, \min =4.5, \max =18.1, \mathrm{sd}=5,2$ ), produced more mucus, the shell and caudal horn were used as blunt pivot that helped changing movement direction and most movements consisted in foot twisting instead of shell rotation (Video 4).

Grooming behavior: These snails groomed themselves with the radula with movements similar to those used when feeding (sample size=58). They groomed their shell, shell lappets, foot, caudal pore and caudal horn (Fig. 2) (Video 5). Sometimes I observed external particles or extra mucus on their caudal pore that could have induced grooming, though most of the time I did not observe any visible cause.

Eating and defecating behavior: It is easy to see when $T$. (T.) costarricanus is eating as the reddish odontophore is visible through the head (Fig. 3 A-B). The snail projects the odontophore to the mouth while eating (Video 6). They mainly feed on epiphyllous mosses, algae and lichens (sample size=63). Occasionally, they eat arthropod's eggs (sample size $=1$ ) and dead bodies (a dead spider) (sample size=1), both observed during a yearlong field work (Fig. 3 C). Snails defecated on underleaves with tentacles extended and the head a little retracted (Video 7). Feces resemble a line of 10-12 small green sausages (Fig. 3 D).

Egg laying behavior: I observed only three specimens laying eggs, one of them on a cut leaf in the terrarium, the others between very wet soil clots. In all cases snails withdrew tentacles and stretched the head. After laying the last egg the snail withdrew the head completely. Then it stretched the head a little and extended the radula to a feeding position, after less than a second they pulled back the radula to a non-feeding position. After laying eggs the snail moved away (Fig. 4). 


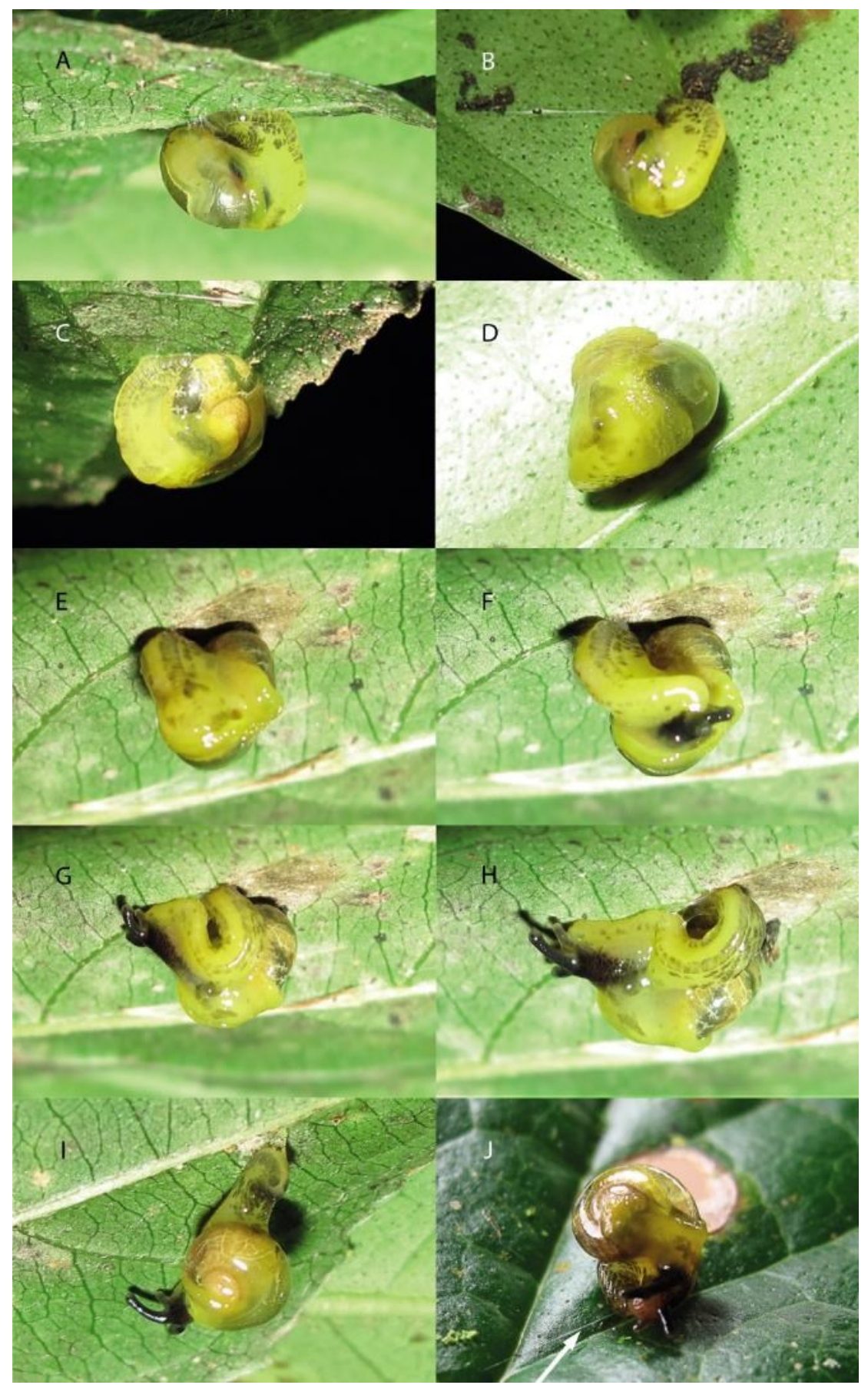

Fig. 1. Detaching process from hanging upside down. A) and B) Head was withdrawn in the shell, but the whole foot was kept outside; only the last part of the foot was attached to the underleaf by mucus from the mucus gland, sometimes a small part of the shell was also attached to the underleaf. C) and D) Shell lappets and mantle lobes were kept out of the shell; mantle lobes cover a big part of the foot and exposed sole; sometimes the shell lappets get a little dehydrated; pneumostome was kept closed most of the time. E) Pneumostome opening got back to a normal rate with reactivation. F) The tentacles and head were pulled out while detaching. G) and $\mathbf{H}$ ) The foot was stretched and the head sole got in contact with the underleaf forming an arch. I) Finally, they freed themselves from the mucus by rising the tail as in the photograph or by sliding away. J) Occasionally, the mucus was too hard, in those cases the snail turned around and broke the thread with the radula. This picture does not belong to the same specimen but shows the thread between the substrate and the caudal pore and the snail cutting it. 


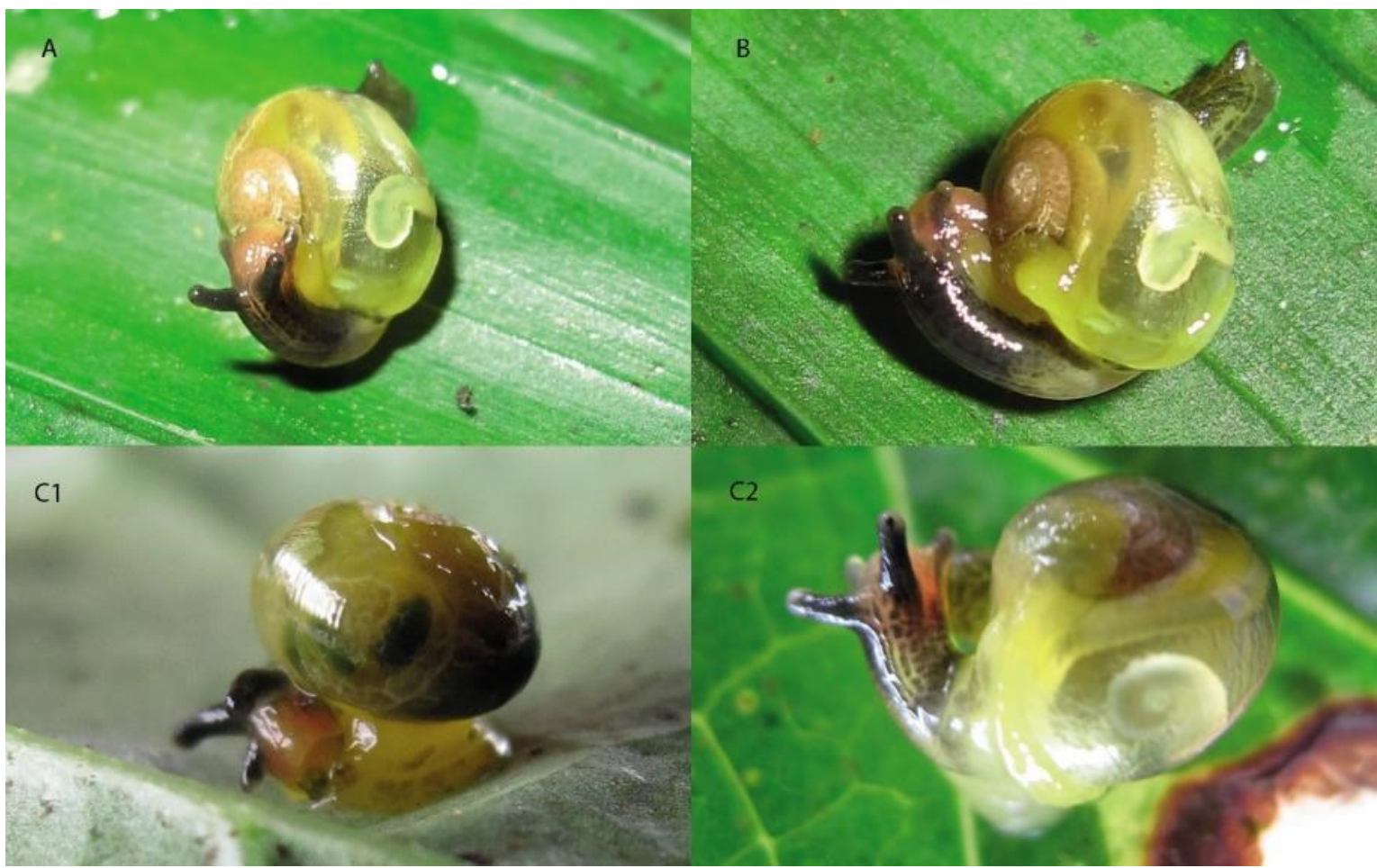

Fig. 2. Grooming. A) Snail grooming its shell lappet. B) Snail grooming its shell. C1-C2) Snail grooming its foot and caudal horn.

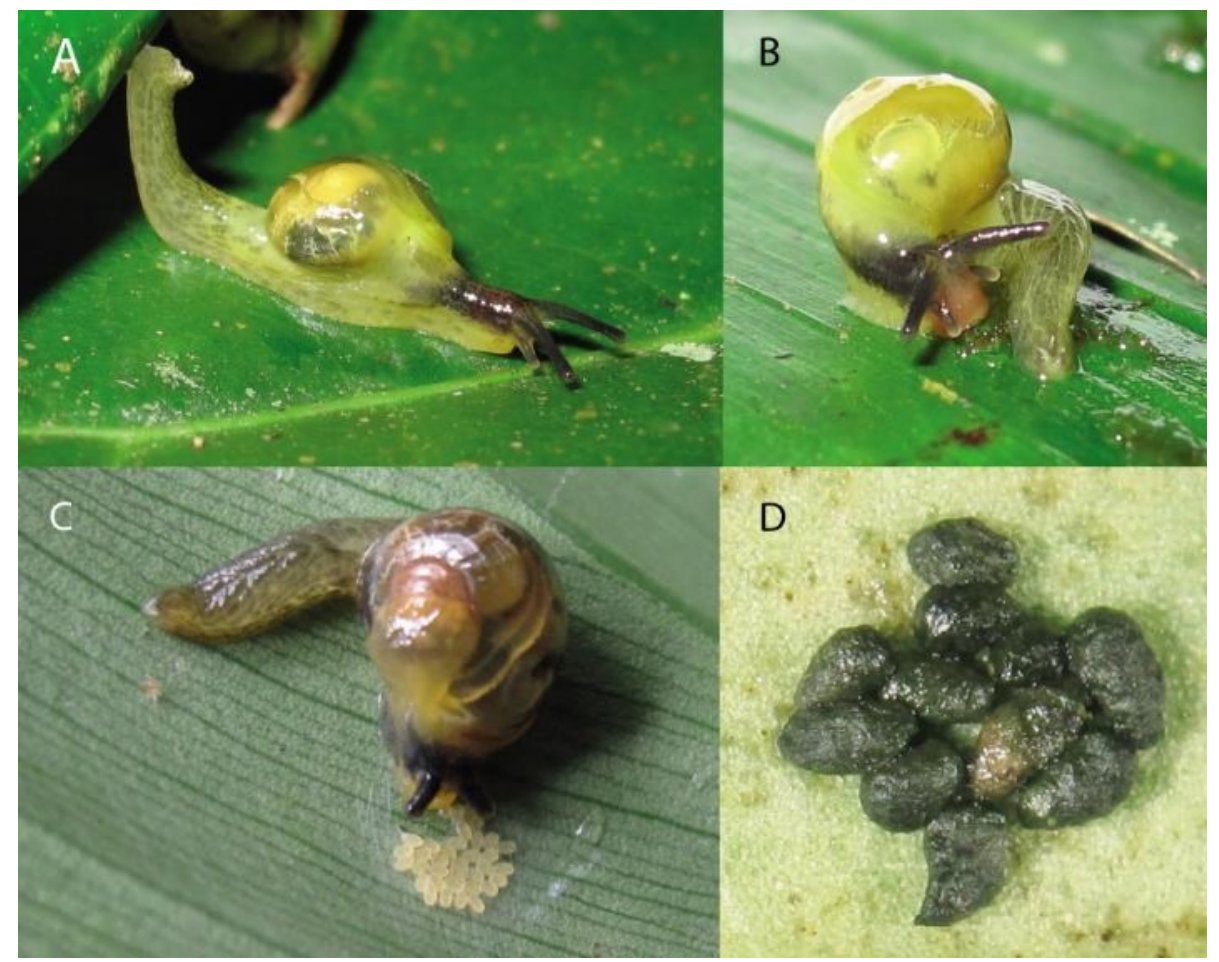

Fig. 3. A) Snail with reddish odontophore in non-feeding position. B) Snail with reddish odontophore extended in feeding position. C) Occasionally this species feeds on arthropod's eggs or dead arthropods. D) Feces of $T$. (T.) costarricanus. 


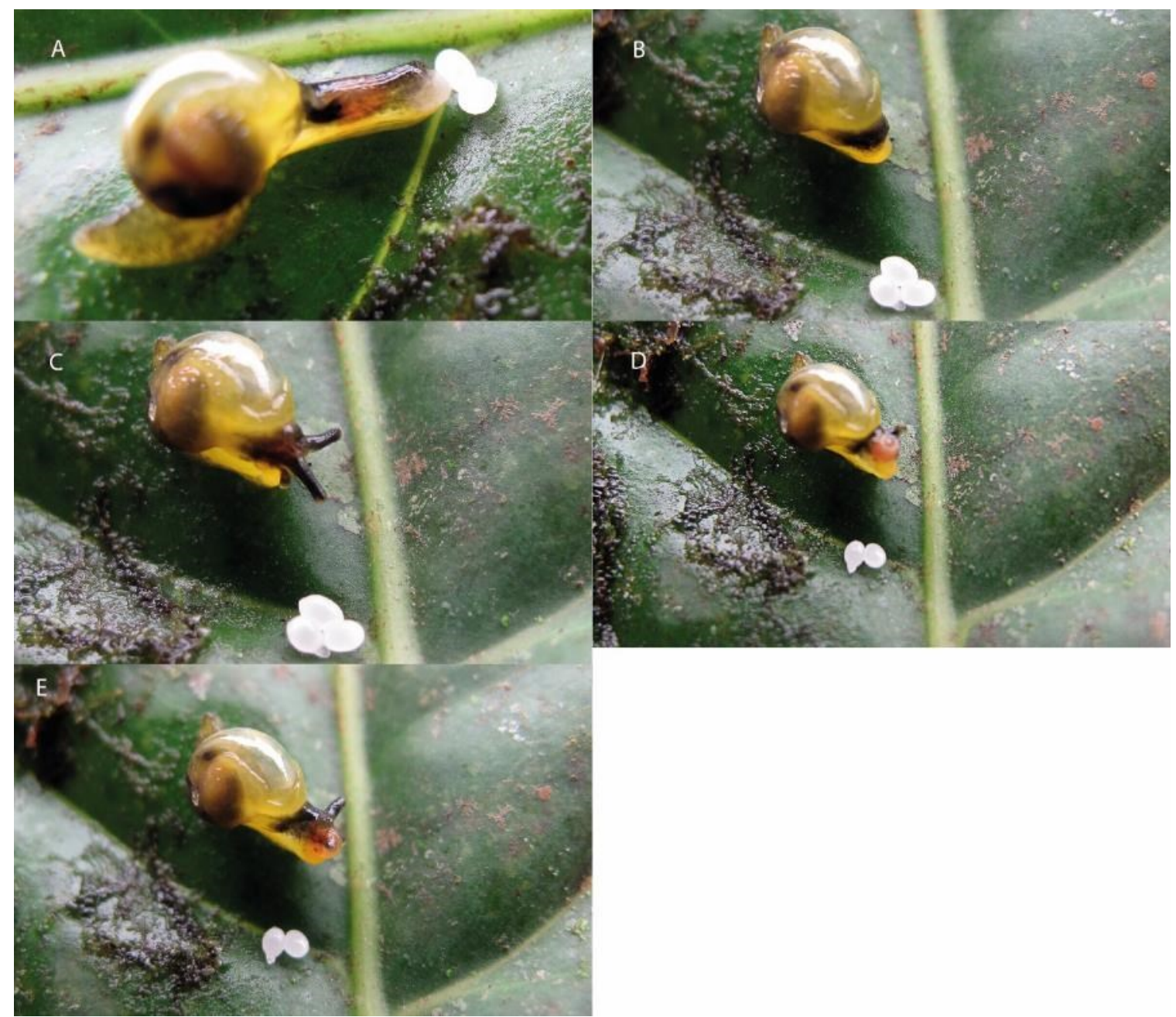

Fig. 4. Egg laying sequence in $T$. (T.) costarricanus. A) Laying eggs. B) After laying the last egg the snail withdrew the head completely. C) Then the snail extended the head and tentacles. D-E) Snail extended the radula in a feeding position. Finally, the radula is pulled back to a non-feeding position and the snail slides away.

\section{DISCUSSION}

This species has an outstanding method to avoid dehydration: hanging upside down like bats during aestivation. But why do they not aestivate as most land snails by hiding inside their shell? Probably, their shell is too small for them to hide inside. Consequently, they do not produce epiphragm layers (Barrientos, 2019b). However, the snail's slow breath reduces water loss while aestivating (Prior, 1985).

Besides these more general characteristics, there are five other features that should be analyzed; some of them point to a distribution restricted to moist environments. First, why do they aestivate on bushes, where they may be exposed to dehydration? Tropical understories have homogenous moisture and temperature, and are protected from heavy rain and direct sunlight by the canopy, i.e. the tropical understory is suitable to moisture friendly biota (Barrientos, 2012). Other land snails that dwell in places with humid and wet regimes also aestivate on bushes and trees, sometimes up to $11 \mathrm{~m}$ above ground (Pomeroy, 1968; Emberton, 1994).

The second characteristic is the contraction of the foot. This may help reducing the surface exposed to evaporation as the integument is responsible for most water loss (Prior, 1985). This also 
may expose less area to parasites and predators. Some slugs, like Arion ater, when attacked, also contract to reduce the exposed area (South, 2012).

The third characteristic is that $T$. (T.) costarricanus detaches the anterior section of their foot from the leaf. This may increase dehydration slightly but may make them resemble galls. On the contrary, active specimens on upperleaves camouflage with moss and other epiphyllous organisms (Barrientos, 2019a). Other species, like bolas spiders, also resemble different things according to the leaf surface were they live (Yeargan, 1994).

The anatomical impossibility of withdrawing the mantle extensions could explain why they keep them out of the shell. Rather, they use them to cover the exposed sole, which makes me think that these extensions have glands that produce substances that reduce evapotranspiration (see Wondrak, 2012). Along this line, Arad (1990) established that the mantle -instead of the shell and epiphragm - is the main water preserving mechanism of Xeropicta vestalis and Trochoidea simulate.

The fifth characteristic is that they stay attached to the leaf by mucus from the caudal gland. The evolution of this behavior is intriguing. On the one hand, the mucus thread associated to "air suspension", reported only in three groups, some Veronicellidae and Annulariidae and Limax maximus, is not produced by the caudal gland (Karlin \& Bacon, 1961; Breure, 2011; Wiktor \& Stawarczyk, 2011). In the case of $T$. (T.) costarricanus, I never observed them suspended in the air; however, sometimes they produce a slime thread when reactivating from the hanging position. If you add the shell rotation and foot twisting while reactivating from aestivation, it is possible that they suspend themselves in the air for seconds or fractions of second. On the other hand, I only found one reference to the function of the stylommatophoran caudal gland: adult specimens of Arion ater produce a mucus ball that is eaten by their partner during copulation, while young stages produce a mucus thread used to descend from trees (Barr, 1927; Elves, 1961). What was found in this research is a new function of the mucus secreted by the caudal gland: attachment to the substrate.

Although predators are not known for this species, the following reactions to disturbance are interpreted here as defensive because they have also been reported as defensive behaviors in other land snails. Land snails' ability to hide inside their shells is widely known. Sticky mucus production, swinging of the shell or cephalopdium, and use of the shell as a shield, have occasionally been reported (Luchtel \& Deyrup-Olsen, 2001; South, 2012; Morii et al., 2016; Gould, Valdez, \& Upto, 2019).

Other behaviors, like lifting and vigorous back and forth foot oscillation have been reported as defense in Velifera gabbi, Ovachlamys fulgens, Derocera reticulatum and Limax maximus (Binney, 1879; Rollo \& Wellington, 1979; Barrientos, 1998). Foot twisting in the euconulids Ovachlamys fulgens and $T$. (T.) costarricanus share the following aspects: aulocopod foot; long foot (considering shell size); small subglobose shell; foot with muscles that allow foot rising and turning in almost $360^{\circ}$; and capacity of reducing caudal horn size from big and conspicuous to considerably small (almost imperceptible in $T$. costarricanus; personal observations). The main difference is that when O. fulgens jumps the caudal horn is big and muscular, and is turned $180^{\circ}$ (touching the leaf) and used as a catapult (Barrientos, 1998). On the contrary, in foot twisting, T. costarricanus, kept the caudal horn small, almost invisible and did not use it as a catapult, and therefore no real jump is done. It is also possible that the speed in which they twist their foot is different.

At a first glance, shell rotation in $T$. (T.) costarricanus is similar to Karaftohelix (Morii et al., 2016). However, in Karaftohelix the main effort is made by muscles under the shell, while in $T$. (T.) costarricanus it is done by the anterior section of the foot. Perhaps Karoftohelix's broader holocopod foot is a better anchor, hence allowing them to use their shell as a club strong enough to knock off predatory beetles. In contrast, in $T$. (T.) costarricanus the objective of this movement is to detach the sole from the substrate. Mucus cohesion allows slugs, snails and semislugs to slide on 
vertical surfaces and stay attached to them, therefore it must be considerably strong. The shell rotation behavior, combined with the foot twisting and the narrower aulocopod foot, gives them the needed elements to detach the sole from the substrate allowing them to fall and hide among leaflitter rapidly.

Shell rotation and foot twisting are vigorous and energy demanding traits, but as shown in this paper, allow them to escape from dehydrating situations. Although I did not see any case in which foot twisting and shell rotation were used to escape from predators, it is quite possible that these traits also allow them to escape from predators and parasites like birds and insects.

The contortion sequence took more time on upperleaves because the animals are not aided by gravity to break free and fall into the leaflitter immediately. The extra mucus produced in these occasions helped by making the surface and the animal more slippery. Slippery animals are harder to catch and slippery surfaces allow more erratic movements.

Grooming has been reported for few land snails and its purpose is still unclear. In Vallonia pulchella grooming is performed on their own eggs (Gugler, 1963). There are two hypotheses for egg grooming: 1) parental care due to cleaning of possible parasites or the inoculation of Artrobotrys oligospora, a nematode parasitic fungus (Kuźnik-Kowalska et al., 2018); and 2) trophic behavior not related to cannibalism (Kuźnik-Kowalska et al., 2018). Grooming has also been described as part of Drymaeus tripictus courtship, where the activity is performed by the specimen with the male role (Barrientos, 2016). In T. (T.) costarricanus grooming is done on their own body and shell, probably for cleaning. Specimens of Helicina funcki, another neotropical species that cannot groom itself, often have algae growing on their shell (pers. obs.). In this case, algae may be a camouflage strategy, but, $T$. (T.) costarricanus has a colour pattern similar to the epiphylls that grow on the leaves where they live (Barrientos, 2019a). Moreover, as in Littorina litorea, algae could retard growing, and therefore the need to clean them up (Wahl, 1997; Vermeij, 2015).

Although eating epiphylls is not a wide spread behavior, other tropical invertebrates also forage on them (Callagan, 1992). Eating eggs and dead bodies of other invertebrates is frequent in some land molluscs like Triodopsis platysayoides (Dourson, 2008), but the scarcity of observed events shows that in T. (T.) costarricanus it is an opportunistic behavior (Speiser, 2001; Ng \& Tan, 2011). Almost all terrestrial mollusks deposit a fecal string that contains a membranous sac made from indigestive material discharged by the digestive gland and larger particles that pass directly to the intestine (Dimitriadis, 2001). However, I could not find information about the anatomical defecation process.

Other snails with oviposition behavior similar to T. costarricanus are Vallonia pulchella and Ovachlamys fulgens (Gugler, 1963; Barrientos, 1998). A completely different oviposition process is done by Gastrocopta pulchella. This species retracts the body into the shell and lays the eggs inside the shell, then the eggs are pushed outside the shell by stretching the body. The snail finishes its work by defecating on the eggs (Gugler, 1963), possibly to hide them from predators and parasites, although Gugler (1963) offers no explanation.

These findings show that the euconulids have a rich repertoire of behaviors that are yet to be studied, and establish a new aestivating posture for the whole class Mollusca.

\section{ACKNOWLEDGMENTS}

Thanks to Maribel Zúñiga Solís, Gabriela Pérez Gómez and Andrea Induni Vizcaino for field and technical assistance. Julián Monge-Nájera, Edna Naranjo and Fred Thompson helped improving this paper.

This paper was partially financied by the project "FEES-CONARE Análisis ecosistémico para la evaluación de la restauración forestal y sus implicaciones en el secuestro de carbono en un bosque nublado" and by the UNED's Research Vicepresidency. 


\section{REFERENCES}

Arad, Z., Goldenberg, S., \& Heller, J. (1989). Resistance to desiccation and distribution patterns in the land snail Sphincterochila. Journal of Zoology, 218(3), 353-364. DOI: 10.1111/j.1469-7998.1989.tb02549.x

Arad, Z. (1990). Resistance to desiccation and distribution patterns in bush-dwelling land snails. Journal of Zoology, 221(1), 113-124. DOI: 10.1111/j.1469-7998.1990.tb03780.x

Arad, Z., Mizrahi, T., Goldenberg, S., \& Heller, J. (2010). Natural annual cycle of heat shock protein expression in land snails: desert versus Mediterranean species of Sphincterochila. Journal of Experimental Biology, 213(20), 3487-3495. DOI: $10.1242 /$ jeb.047670

Asami, T. (1993). Interspecific differences in desiccation tolerance of juvenile land snails. Functional Ecology, 7(5) 571-577. DOI: $10.2307 / 2390133$

Barrientos, Z. (1998). Life history of the terrestrial snail Ovachlamys fulgens (Stylommatophora: Helicarionidae) under laboratory conditions. Revista Biología Tropical, 46(2), 369-384. Retrieved from https://revistas.ucr.ac.cr/index.php/rbt/article/view/19628/19714

Barrientos, Z. (2005). Moluscos terrestres de los páramos de Costa Rica. In M. Kappelle \& S.P. Horn (eds.), Páramos de Costa Rica (pp. 501- 512). Santo Domingo de Heredia, Costa Rica: Instituto Nacional de Biodiversidad (INBio)

Barrientos, Z. (2012). Dynamics of leaf litter humidity, depth and quantity: two restoration strategies failed to mimic ground microhabitat conditions of a low montane and premontane forest in Costa Rica. Revista de Biología Tropical, 60(3), 1041-1053. Retrieved from https://revistas.ucr.ac.cr/index.php/rbt/article/view/18582/22978

Barrientos, Z. (2016). Reproductive system, mating behavior and basic ecology of an extremely rare tropical snail: Drymaeus tripictus (Stylommatophora: Bulimulidae). Revista de Biología Tropical, 64(1), 55-68. Retrieved from https://www.scielo.sa.cr/pdf/rbt/v64n1/0034-7744-rbt-64-01-00055.pdf

Barrientos, Z. (2019a). A new genus of semislugs (Stylommatophora, Euconulidae) from Costa Rica and a review of the genus Velifera (Stylommatophora, Euconulidae). Revista Biología Tropical, 67(6), 1313-1358. DOI: 10.15517/RBT.V67I6.36105

Barrientos, Z. (2019b). Demography of the land snail Tikoconus (Tikoconus) costaricanus (Stylommatophora: Euconulidae) in tropical low montane and premontane forests, Costa Rica. Revista Biología Tropical, 67(6), 1449-1460. DOI: 10.15517/RBT.V67I6.36201

Barr, R. A. (1927). Memoirs: Some Notes on the Mucous and Skin Glands of Arion ater. Journal of Cell Science, 2(283), 503525. Retrieved from https://jcs.biologists.org/content/joces/s2-71/283/503.full.pdf

Binney, W. G. (1879). On the jaw and lingual dentition of certain Costa Rica Land Shells collected by Dr. William M. Gabb. Annals of the New York Academy of Sciences, 1(9), 257-262, PI.XI.

Breure, A. S. (2011). Dangling shells and dangerous spiders: malacophagy and mimicry in terrestrial gastropods. Folia conchyliologica, 7, 7-13. Retrieved from https://www.researchgate.net/publication/254879625_Dangling_shells_and_dangerous_spiders_malacophag y_and_mimicry_in_terrestrial_gastropods

Callaghan, C. J. (1992). Biology of epiphyll feeding butterflies in a Nigerian cola forest. Journal of the Lepidopterists' Society, 46(3), 203-214. Retrieved from http://images.peabody.yale.edu/lepsoc/jls/1990s/1992/1992-46(3)203Callaghan.pdf

Cook, A. (2001). Behavioural Ecology: On Doing the Right Thing, in the Right Place at tha Right Time. In: Barker, G.M. (ed). The biology of terrestrial mollusks (pp. 447-488.). New York, USA: CABI publishing. 
Dimitriadis, V. K. (2001). Structure and Function of the Digestive System in Stylommatophora. In: Barker, G.M. (ed). The biology of terrestrial mollusks (pp. 237-257). New York, USA: CABI publishing.

Dourson, D. C. (2008). The feeding behavior and diet of an endemic West Virginia land snail, Triodopsis platysayoides. American Malacological Bulletin, 26(1/2), 153-160. DOI: 10.4003/006.026.0215

Elves, M. W. (1961). The histology of the foot of Discus rotundatus, and the locomotion of gastropod Mollusca. Journal of Molluscan Studies, 34(6), 346-355. DOI: 10.1093/oxfordjournals.mollus.a064880

Emberton, K. C. (1994). Morphology and aestivation behaviour in some Madagascan acavid land snails. Biological Journal of the Linnean Society, 53(2), 175-187. DOI: 10.1111/j.1095-8312.1994.tb01008.x

Giokas, S., Pafilis, P., \& Valakos, E. (2005). Ecological and physiological adaptations of the land snail Albinaria caerulea (Pulmonata: Clausiliidae). Journal of Molluscan Studies, 71(1), 15-23. Retrieved from https://academic.oup.com/mollus/article/71/1/15/997866

Gould, J., Valdez, J. W., \& Upton, R. (2019). Adhesive defence mucus secretions in the red triangle slug (Triboniophorus graeffei) can incapacitate adult frogs. Ethology, 125(8), 587-591. DOI:10.1111/eth.12875

Gugler, C. W. (1963). The eggs and egg-laying habits of some Midwestern land snails. Transactions of the Kansas Academy of Science (1903-), 66(2), 195-201. DOI: 10.2307/3626560

Hyman, L. H. (1967). The Invertebrates: Mollusca 1 (Vol VI). New York, USA: McGraw-Hill.

Karlin, E. J., \& Bacon, C. (1961). Courtship, mating, and egg-laying behavior in the Limacidae (Mollusca). Transactions of the American Microscopical Society, 80(4), 399-406. DOI: 10.2307/3223598

Kuźnik-Kowalska, E., Proćków, M., Pląskowska, E., \& Pokryszko, B. M. (2018). Egg Grooming in Vallonia Snails-AntiParasite Defence or Trophic Behaviour? Polish Journal of Ecology, 66(1), 64-70. DOI: 10.3161/15052249PJE2018.66.1.007

Le Ferrand, H., \& Morii, Y. (2020). Structure-behaviour correlations between two genetically closely related snail species. Royal Society Open Science, 7(1), 191471. DOI: 10.1098/rsos.191471

Luchtel, D. L., \& Deyrup-Olsen, I. (2001). Body wall: form and function. In: Barker, G. M. (ed). The biology of terrestrial mollusks (pp. 147-178). New York, USA: CABI publishing.

Moreno-Rueda, G., Ruiz-Ruiz, A., Collantes-Martín, E., \& Arrébola, J. R. (2009). Relative importance of humidity and temperature on microhabitat use by land snails in arid versus humid environments. p. 331-343. In: FernándezBernal, A. \& De la Rosa, M.A. (Eds). Arid Environments and wind erosion. Nueva York, USA: Nova Science Publishers.

Morii, Y., Prozorova, L., \& Chiba, S. (2016). Parallel evolution of passive and active defence in land snails. Scientific reports, 6, 35600. Retrieved from https://www.ncbi.nlm.nih.gov/pmc/articles/PMC5105203/

Naranjo-García, E. (2003). Moluscos continentales de México: terrestres. Revista de Biología Tropical, 51 (Suppl. 3), 483493. Retrieved from https://revistas.ucr.ac.cr/index.php/rbt/article/view/26396/26584

Newell, P.F., \& Machin, J. (1976). Water regulation in aestivating snails. Cell and tissue research, 173(3), 417-421.

Pomeroy, D. E. (1968). Dormancy in the land snail, Helicella virgata (Pulminata: Helicidae). Australian Journal of Zoology, 16(5), 857-869. DOI: 10.1071/zo9680857

Prior, D. J. (1985). Water-regulatory behaviour in terrestrial gastropods. Biological Reviews, 60(3), 403-424. DOI: 10.1111/j.1469-185X.1985.tb00423.x 
Ng, T. H., \& Tan, S. K. (2011). Observations of land snails feeding on the eggs of Pomacea canaliculata (Lamarck, 1822)(Mollusca: Gastropoda). Nature in Singapore, 4, 79-83. Retrieved from https://lkcnhm.nus.edu.sg/app/uploads/2017/06/2011nis079-083.pdf

Rahman, M.S., \& Raut, S.K. (2010). Factors inducing aestivation of the giant African land snail Achatina fulica Bowdich (Gastropoda: Achatinidae). Proceedings of the Zoological Society, 63(1), 45-52.

Reber, A., Purcell, J., Buechel, S., Buri, P., and Chapuisat, M. (2011). The expression and impact of antifungal grooming in ants. Journal of evolutionary biology, 24(5), 954-964. DOI: 10.1111/j.1420-9101.2011.02230.x

Rollo, C.D., \& Wellington, W.G. (1979). Intra- and inter-specific agonistic behavior among terrestrial slugs (Pulmonata: Stylommatophora). Canadian journal of Zoology, 57, 846-855. DOI: 10.1139/z79-104

South, A. (2012). Terrestrial slugs: biology, ecology and control. Berlin, Germany: Springer Science \& Business Media.

Sparks, J. (1967). Allogrooming in Primates: a Review. In: Morris D. (ed.). Primate ethology. pp. 148-175. Aldine, Chicago, USA: Aldine Transaction. Retrieved from https://psycnet.apa.org/record/2006-01577-004

Speiser, B. (2001). Food and feeding behaviour. In: Barker, G. M. (ed). The biology of terrestrial mollusks (pp. 259-288). New York, USA: CABI publishing.

Vermeij, G. J. (2015). Gastropod skeletal defences: land, freshwater, and sea compared. Vita Malacologica, $13,1-25$. Retrieved from https://www.repository.naturalis.nl/document/621888

Wahl, M. (1997). Increased drag reduces growth of snails: comparison of flume and in situ experiments. Marine Ecology Progress Series, 151, 291-293. Retrieved from https://www.int-res.com/articles/meps/151/m151p291.pdf

Wiktor, A. \& Stawarczyk, T. (2011). An unusual mode of locomotion of an Ecuadorean slug Belocaulus sp. (Mollusca: Gastropoda: Vaginulidae). Folia Malacologica, 19(4), 277-278. DOI: 10.2478/v10125-011-0007-6

Wilson, S. N., Sindi, S. S., Brooks, H. Z., Hohn, M. E., Price, C. R., Radunskaya, A. E., ... \& Fefferman, N. H. (2020). How Emergent Social Patterns in Allogrooming Combat Parasitic Infections. Frontiers in Ecology and Evolution, 8, 54. DOI: $10.3389 /$ fevo.2020.00054

Withers, P., Pedler, S., \& Guppy, M. (1997). Physiological adjustments during aestivation by the Australian land snail Rhagada tescorum (Mollusca: Pulmonata: Camaenidae). Australian Journal of Zoology, 45(6), 599-611.

Wondrak, G. (2012). Monotypic gland-cell regions on the body surface of two species of Arion: ultrastructure and lectinbinding properties. Journal of Molluscan Studies, 78(4), 364-376. DOI: 10.1093/mollus/eys024

Yeargan, K. V. (1994). Biology of bolas spiders. Annual review of entomology, 39(1), 81-99. Retrieved from http://www.annualreviews.org/doi/abs/10.1146/annurev.en.39.010194.000501 